\title{
Collective bargaining and new work regimes: 'too important to be left to bosses'
}

\section{Patricia Findlay, Alan McKinlay, Abigail Marks and Paul Thompson}

\begin{abstract}
The formal negotiations process remains perhaps the least-studied moment of collective bargaining. Drawing on ideal types of 'distributive' and 'integrative' bargaining and the 'formal/informal' distinction, this article reports non-participant observation and ethnographic research into the negotiations process that enabled a change agreement in a British multinational, hereafter anonymised as FMCG. Informal bargaining relations provided the backdrop to - and emerged within - the formal negotiations process. Formal bargaining established new employment contracts based on a simplified internal labour market and generated the joint governance processes to enable and regulate the change process. Neither management nor union strategy was wholly derived from rational, interest-based positions. The negotiations process was essential to strategy formation and to the emergence of sufficient integrative' bargaining for all parties to devise and approve new processual institutions and norms to deliver a more flexible labour process and to restore the long-run viability for 'distributive' bargaining.
\end{abstract}

\section{INTRODUCTION}

The importance of formal collective bargaining in remaking work organisation has long been downplayed. Studies of human resource management or new management techniques have focused on the shopfloor. This partly reflects the diminished importance of the institutions and processes of formal collective bargaining, and it is true that management have driven through significant changes in work organisation by bypassing formal governance structures. However, this is not the only route management have chosen to reshape labour processes. In the car industry, for instance, all the major companies initiated new production regimes through formal collective 
bargaining (Foreman-Peck et al., 1995; Martinez Lucio and Weston, 1992a; Stewart and Garrahan, 1995). The formal level has been used both as a platform to rewrite contracts and to cast custom and practice into doubt. Indeed, it is too easy to exaggerate the contrast between formal/negotiated and informal/forced change: 'Viewed through a negotiations lens, unilateral action and reaction represent early moves in an unfolding, back-and-forth process. The process may involve escalation and collapse on the part of one or both parties. The process may even involve dialogue and increased understanding - reflected in joint decisions and mutual agreements. Whether or not it intends to negotiate, a party taking unilateral action to drive a change that affects others ... will inevitably find itself on a path of negotiated change' (Walton et al., 1994: 1). We hope to demonstrate that formal collective bargaining is both a critical arena for management seeking to legitimise radical change programmes and for trade unions to become embedded in the governance institutions of the new workplace.

Critical analyses tend to overstate the strategic capacity of management, assuming that the most important dimension of management strategy is planning. This is an increasingly anachronistic view of management strategy, which-exceptional moments aside - owes as much to emergence as to formal planning. We analyse the organisational, industrial relations and product market context in the opening section. Trade unions and employees should not be regarded as external stakeholders or pressure groups in management decision making. When considering radical shifts in work organisation, management teams anticipate shop steward and workforce responses. Shop stewards are the ever-present ghosts at the management table. Trade unions are integral to management strategy. Formal planning, particularly the setting and rationale for formal collective bargaining, is considered in the second section. The dynamic between planned and emergent management strategy and the role of union negotiators is considered in the third section.

This article focuses on the negotiation of a seminal collective agreement'Watershed' - in FMCG, a major British multinational, whose objective was to deliver short-term cost savings through voluntary redundancies and significant, durable changes in work organisation. A combination of routinised, individualised work design and informal job control strategies had embedded a rigid, inflexible labour process and a deeply adversarial form of collective bargaining. For FMCG's executives, a shift from individualised tasks to teamworking was critical to enhanced flexibility and sustainable competitiveness. The research traced the impact of this change process in two key FMCG sites over four years. Over 90 extended interviews were conducted with executive and operational managers, shop stewards and line workers (Burawoy, 2003; Burawoy et al., 1991; Friedman and McDaniel, 1998). Two workforce and management surveys were conducted, covering all aspects of employment, authority and union representation (see Marks et al., 1998). The research team had access to all phases of the collective bargaining process, including unlimited access to the shop stewards and the boardroom, and were able to observe both formal and informal meetings between management and union negotiators. Researchers were non-participant observers of all stages of the negotiations process, complemented by formal interviews with key players before, during and after agreement. We have taken care to report something of the language of the negotiators to demonstrate the visceral, emotional and humorous nature of these exchanges.

The academic literature has little to say about the process of formal collective bargaining, focusing rather on the informal level on the shopfloor or the outcomes of 
formal collective bargaining (Brown, 1972). There are few empirical studies of negotiations processes that go beyond Walton and McKersie's (1965) classic account of 'integrative', 'distributive' and 'mixed mode' bargaining (Kelly, 1998: 17; Martin, 1992: 98). Integrative and distributive bargaining are ideal types that assign no moral priority to one or other mode. Integrative bargaining involves a cooperative problemsolving approach within a high-trust relationship in which all parties consciously forsake opportunism. This process is cumulative, self-reinforcing and, above all, learned (Guest et al., 2008; Lewicki and Bunker, 1996). The bargaining relationship rests upon iterative social processes, not individual predispositions. Social cues and shared experience prompt all parties to recognise the value of their high-trust relationship and that there has been no exploitation of each others' vulnerabilities for tactical gain. This establishes a virtuous cycle that generates and consolidates high trust and opens up possibilities for expanding the scope of integrative bargaining. As integrative bargaining becomes more embedded, so the problem-solving capacity of the relationship increases and organisational performance improves. Inevitably, however, as the bargaining parties reduce their monitoring of each others' behaviours - in itself an efficiency gain - so the possibilities for, and potential returns to, opportunism increases. Any serious infraction of high-trust norms is, therefore, likely to jeopardise the viability of integrative bargaining institutions, processes and behaviours. Distributive bargaining, on the other hand, conforms to the familiar stereotype of collective bargaining. All parties are engaged in zero-sum bargaining: a 'gain' for one party entails a 'loss' for another in, for example, reward, status, power or authority. There is none of the cooperative, problem-solving or mutual gains of pure integrative bargaining. Rather, each party begins from a presumption of constrained bad faith, monitors behaviours for opportunism, and seeks to establish rules that specify the scope and rules of engagement for collective bargaining. Collective bargaining becomes a series of formalised, contested and unstable equilibria. Industrial relations becomes a staccato process in which relative gains and losses are calculated contractually. In contrast to integrative bargaining, the dynamic of the distributive mode is insular, closed, relatively short-term and based on narrow selfinterest. The attractions of distributive bargaining are that, for relatively weak parties, it establishes clear minimum standards while, for the powerful, it consolidates their strengths and offers a vehicle to offset any temporary reversal—or to deploy their strength to better effect in the future. For unions, the attractions of distributive bargaining are its congruence with member expectations; its visibility and adversarial nature that prioritises member interests; and its formality that compels a greater degree of disclosure by all parties, permitting comparisons of bargaining outcomes and negotiator effectiveness. For management, the main advantage of distributive bargaining is that it fixes contracts and makes labour costs predictable for a given period, and incurs none of the costs or risks involved in moves towards a more cooperative integrative mode. The disadvantages for management are the inflexibility and closed nature of distributive bargaining that offers little scope for wider workforce engagement, mutual gains from innovations in work organisation, or for any step change in labour productivity.

In practice, all bargaining events and processes necessarily entail some measure of both modes of thinking and behaviour. Walton and McKersie (1965: 370) even insist that for individual decision makers, the two modes are complementary: the dilemma is to estimate the greatest gain to be derived from skewing a mixed mode strategy towards integration or distribution. Success in securing the outcome desired by one 
party at the outset need not have resulted from distributive bargaining. Rather, the negotiation process, however adversarial, necessarily generates knowledge about each others' underlying priorities that may trigger some limited joint problem solving within a primarily distributive mode. Integrative processes may be implicit, even hidden, within distributive bargaining, and vice versa. During the 'Watershed' negotiations, as we shall see in section two, management and union representatives moved between both modes intuitively, deliberately, and as a result of their shared experience.

\section{MANAGEMENT STRATEGY AND UNION ORGANISATION}

FMCG operates in a global market experiencing secular decline and all segments and regions are increasingly contested. Competitiveness hinges on brand management and market responsiveness. FMCG is the most important production division of its conglomerate parent, hereafter anonymised as PLC. Poor market and financial performance increased the pressure on operations management to experiment with new working practices, including forms of union-employer partnership and teamworking. Both a cultural change programme and a previous attempt to reorganise the workplace through formal collective bargaining achieved little. Management initiatives may have increased employee awareness of the competitive pressure for reshaping work but compounded deep-seated mistrust. Misgivings about management competence and opportunism made the workforce extremely reluctant to endorse any notion of partnership. Indeed, FMCG's attempt to introduce a wide-ranging enabling agreement foundered on the workforce's perception that this was a licence for management to redraw the labour process freed from the collective agreements which had regulated the shopfloor for two decades.

For almost a decade, FMCG's management of collective bargaining had been constrained by a conservative personnel policy increasingly at odds with an assertive line management. In turn, operations management had limited support from a PLC board whose determination to maintain throughput was at the cost of leaving archaic production regimes intact. Internal restructuring had altered FMCG's status within PLC (Marginson et al., 1994; Webb, 1996). FMCG had been a fully integrated company with manufacturing, marketing and finance functions. Corporate restructuring stripped FMCG of its marketing and finance functions, reducing it to a cost centre whose financial targets were set by transfer prices decided by PLC. The purpose of the restructuring was to pressurise FMCG into reducing production costs. For over two years FMCG management personnel - from the shopfloor to the boardroomhad been significantly altered. Senior operational management had been overhauled while the renamed Human Resources (HR) function had moved centre stage in the FMCG executive. In particular, FMCG's new HR director enjoyed strong political backing from PLC. All other objectives, including nebulous 'cultural' targets, were secondary to driving down labour costs.

FMCG manual workers are virtually completely unionised. Process workers are members of the GMB union with skilled engineers in AMICUS. There had been no erosion of long-established trade union facilities; the ratio of steward to members remained approximately one to between 30 and 40. The GMB convenor remained a de facto full-time post cloaked in the convenience of a storeman's job located in an office next to the personnel department (similarly, Milward et al., 1992: 110-117). The convenor and personnel manager had sucked all important industrial relations decisions into their personal domain. Beneath a veneer of durable steward organisation 
there was a progressive loss of steward tactical and strategic capability. Neither the GMB nor AMICUS shop stewards had developed any cohesive approach to shopfloor bargaining: episodic contract negotiations were the only moments at which the stewards pursued a common approach. Even at such moments of maximum collectivity, the stewards regarded their main role as representatives of specific constituencies. Individual shop stewards operated independently and opportunistically with little central monitoring or control. There was no joint shop stewards' committee coordinating the tactics of process or skilled workers.

Few shop stewards faced elections; most were reluctant conscripts or resigned incumbents. The AMICUS deputy convenor accepted his stewardship after a year in which his department was without representation: "nobody would take the job. Everybody signed the form to get somebody else to take the job. It was a bad situation to be in because everybody had to do their own negotiating. I took over, I am basically stuck with it now'. The process shop stewards were instrumental representatives rather than ideologically committed to sustaining their union's presence on the shopfloor (Batstone et al., 1977; Nicolson et al., 1981). Skilled stewards, moreover, regarded themselves as 'active engineers', guardians of craft identities, 'as opposed to active shop stewards or union officials'. The workforce perceived their shop stewards as having limited understanding and marginal influence over the gradual introduction of new management techniques. Support in principle for a wider role for trade unions in shaping work reorganisation was paralleled by widespread anxiety that lay delegates were incapable of protecting the workforce's interests in practice. The FMCG workforce survey revealed that before 'Watershed', fewer than 20 per cent of the process workers regarded their stewards as having any influence over work organisation, overtime allocation or the decisions of frontline managers. The most extreme dissatisfaction registered was in manning levels where almost two-thirds of nonskilled respondents felt that their union poorly represented their interests.

The only positive rating GMB stewards received from their members was in representing workers ensnared in the company's formal disciplinary procedure. Viewed from the process lines, shop stewards were incapable of gaining ground through informal collective bargaining: the emergent shopfloor strategy was to defend fixed positions centred on custom and practice. The prime example was the relief system that guaranteed process workers 12 minutes off-line per hour. Given the certainty that FMCG's increasingly assertive management would target this glaring inefficiency, the optimum solution was to prise a one-off payment for surrendering such practices through formal collective bargaining. Strategically, the stewards were not leaders but hostages of the shopfloor. Widespread and profound shopfloor scepticism, coupled with the stewards' limited strategic capability, produced a deeply defensive workplace trade unionism. Any move towards a teamworking regime, with its uncertainties about tasks and governance, could only be brokered by formal collective bargaining.

\section{PREPARING FOR THE NEGOTIATIONS PROCESS}

Management's preparations for the 'Watershed' negotiations lasted for approximately four months and were led by HR. Operational management was excluded. The cornerstone of management's negotiations strategy was to appropriate union bargaining agendas - job security, training and improved wage rates - to legitimise the introduction of new working practices. The unions' demands were straightforward: enhanced terms and conditions; improved job security; and a tighter specification of 
core manning levels for three years. The unions made no effort to initiate debate about training, or the remaking of shopfloor governance, far less teamworking.

FMCG had never conducted any risk assessment before collective bargaining, relying instead on the intuitive judgements of the personnel director. Management's first step for the 'Watershed' negotiations, by contrast, was a formal assessment of the power and authority of the company, the shop stewards and union officials. Shop steward power, company strategists concluded, was real only in so far as it was accepted as such by management. Management, by contrast, wielded real powers:

We have the ability to transfer products to other operations in the Group. We control all formal communication channels. We have the legitimacy of previous Agreements to support change, and we have the time and resources to plan [FMCG HR Briefing Document].

FMCG's management had never adopted a self-confident, assertive approach to collective bargaining. This management legacy reduced its nominal powers in the eyes of union negotiators. Simply to exercise its superior power through 'exploitative tactics' would jeopardise the company's aim to establish a clear agenda of work reorganisation, which the unions could only influence through partnership. Unlike the process workers, skilled engineers occupied 'a pivotal role': 'without their goodwill, production would grind to a halt'. For two decades the engineers had used their strategic position to secure extensive job controls and high basic wage rates. For management, a central plank of the negotiations' strategy was the need to restore control to shopfloor management. FMCG's negotiations strategy was twin-track (see Storey, 1992: 250-251). First, assimilate GMB shop stewards into a partnership process to deliver 'Watershed': a strategy that required a new shopfloor governance process. Five joint union-management project teams would assume responsibility for implementing changes in employment contracts and work organisation. An important secondary effect, noted management, was the opportunity to create a layer of competent union representatives, not necessarily stewards, as advocates of partnership and cultural change (similarly, Samuel, 2005: 73). Any overruns were to be settled by local management unilaterally. Second, given the engineers' irreplaceable knowledge, confrontation was not a viable option. The 'radical' alternative, FMCG's HR director informed the PLC board, was to incorporate all of AMICUS's opening demands into 'Watershed' to 'create a win/win deal with something for all sides. If successful we could significantly reduce one of the major barriers to change at FMCG'. Only an integrative deal based on constructing a mutual gains workplace had any real hope of securing the unions' and the workforce's active consent. Management sought to combine 'forced' and 'integrative' strategies to deliver rapid and durable results (Walton et al., 1994: 25-28). All engineers would move from hourly to staff status on completion of a training programme designed to blur the boundary between mechanical and electrical competencies. Training and a modest relaxation of demarcation lines was to be accompanied by shifting engineers from functional to line control, to accelerate switching between different products and to introduce a preventative maintenance regime. These were not minor operational adjustments but held the prospect of far greater managerial control over engineers' labour time and deployment.

The first stage in FMCG's strategy formulation was contained wholly within HR (Marks et al., 1997). Operational management did not shape the strategy with recommendations for work reorganisation. Only after the structure of 'Watershed' was 
established were successive drafts circulated to operational management. This sequence maintained HR's control of the negotiations strategy and ensured that production managers could not distance themselves from 'Watershed'. While shortrun cost objectives could be met by voluntary redundancy, HR was conscious that 'Watershed' had to be 'delivered by the line'. Only significant labour process change could deliver the medium-term improvements in labour and capital productivity. Criticism of HR's strategy was unlikely since newly appointed managers were aware that delivering 'Watershed' was their key task, and established managers were disabled by their complicity in FMCG's poor manufacturing record: 'we've got a company here in which it is difficult to achieve incremental change because you've got to pay for every time someone walks and whistles at the same time' (HR director Q\&A with operational managers). The strategic objective was to set the stage for a radical reshaping of the labour process by terminating labour contracts which embedded the status quo (Black and McCabe, 1996; Dunn and Wright, 1994; Ingram, 1991).

Once the contours of management strategy were established, attention turned to the negotiations process. This was not a secondary issue since FMCG's strategy could only be delivered through formal collective bargaining. Determining the location, duration and pace of negotiations was at management's discretion. For management, the negotiations were to be continuous, off-site and insulated from shopfloor pressure. 'If we stop [negotiating] for a few days', the HR director reflected, 'the stewards always come back more horrible bastards than before'. Shop stewards were to be paid their full earnings - including bonus and overtime - throughout the negotiations and were relieved of their duties. Management tried to control the flow of information between the negotiations and the plants: formally, only joint communiqués were permissible. By removing the shop stewards from the plants, management minimised the pressures on them from their constituents. Management had exclusive access to informal communications through 'our ambassadors on the shopfloor', frontline management. Equally, management could 'drip, drip our leaks and rumours' into the factories by, for instance, leaving internal briefings in photocopiers. Management developed its bargaining objectives over a four-month period, nullified potential opposition to 'Watershed' from operations management or PLC and orchestrated the format of the negotiations.

Surprisingly, given the existence of a partnership agreement for general workers, there was no GMB early involvement in the design of 'Watershed'. But the partnership agreement had yielded little. The unions were aware that management were involved in the design of a new agreement, but remained aloof, despite management overtures. The GMB balked at being proactive: 'we felt at the time that he was trying to get us to hang ourselves'. Yet they were not entirely unprepared for the negotiations. The stewards' intimate knowledge of the workplace allowed them to anticipate management's concerns. The involvement of their union full-time office (FTO) in other change agreements provided a base-line model, which reflected the GMB's national agenda. In collective bargaining, GMB officials conform to a model agreement based on centrally approved objectives (Heery, 1996: 181-182). By the mid-1990s the GMB was the standard-bearer of 'industrial partnership' in which employee involvement was a crucial bargaining objective (Martinez Lucio and Weston, 1992b: 82-83; Undy et al., 1996: 60-61). In FMCG, comparatively weak shop stewards' organisation combined with the GMB's national strategy that defined the full-time officer as the pivot of the strategy and process of collective bargaining (Kelly and Heery, 1994: 145-146). 


\section{NEGOTIATIONS}

FMCG's products experienced highly seasonal demand, imposing real pressure on management to agree 'Watershed' quickly. FMCG's previous attempt to introduce flexibility had failed because negotiations had stretched over eight months and had become enmeshed in innumerable small disputes. FMCG offered a one-off incentive payment if the workforce accepted 'Watershed' within six weeks of negotiations opening.

The first week of the 'Watershed' negotiations was frustrating for the eight-strong management team. The FMCG strategy demanded that 'Watershed' be agreed in its entirety: 'sign up for the whole fish rather than try to pick the bones out of it'. Management's tactic was to seek agreement clause by clause: each day ended with a summary of what had been agreed to build momentum. Operations managers were instructed by HR to take every opportunity to socialise with 'their' stewards. Initially, only the union officers participated in the public exchanges. After hearing the HR director read out each clause, they simply acknowledged that they understood or required clarification. Confronted with near silence for two days, management were discomfited to the extent that in their backroom, one production manager kicked over a chair in anger at the stewards' 'dumb insolence'. The production managers had wildly contradictory perceptions of the shop stewards. On the one hand, the stewards were viewed as powerful figures who moulded their members' opinion and, through their encyclopaedic knowledge of custom and practice, subverted management decisions. On the other hand, the managers dismissed the stewards as unrepresentative, who could be easily outmanoeuvred through direct communications.

Only after the complete document had been run through did the officials make any substantive contributions to the negotiations. The officials first targeted general clauses regarding flexibility in terms of task, time or labour transfers. 'I've heard this all my life', the GMB official explained. 'I've negotiated things in and managers don't know what to do with them'. For every general, enabling statement that increased managerial prerogative to reshape work organisation, the union negotiators demanded details about job content, grading and training. Without such extensive detail, the officials warned, Watershed was 'a dead letter: I can't deliver it for you so I can't accept any of it'. The officials' position was subtle: the only agreement that they could accept was one that they could 'sell' to the shopfloor. By requesting extensive detail about exactly what 'flexibility' meant to different grades in different departments they were not obstructing ratification but, rather, making it possible. The GMB official was refusing any agreement set unilaterally by managers as the negation of collective bargaining while opening up the possibility of integrative and distributive bargaining.

Management was anxious to avoid being 'sucked into the detail' about departmental idiosyncrasies that would render a corporate approach impossible. Privately, the HR director warned the GMB official that FMCG was prepared to issue three months' notice of a change in contract and simply redraw working hours and practices. This was an extreme statement of intent of pure distributive bargaining in which one party dominates. This threat proved to be the GMB official's most effective argument in facing down any rank-and-file opposition. Work reorganisation was certain, he constantly reminded the shop stewards, irrespective of their opposition. The stewards' role was to maximise the benefits to their members; to embed their influence over 'the new shopfloor'; and to sustain the union's authority (similarly, see 
Bacon and Storey, 2007; Geary and Roche, 2003: 34; Marks et al., 1998). The language and practices of integrative bargaining was the only possible route to effective representation and, by implication, mutual or distributive gains for the unions.

Both management and union negotiators had to find a rhetorical device for the stewards on their return to their factories. The brute threat of compulsion was inadequate. For FMCG management, the turning point was an intervention by the HR director, which fundamentally altered the nature of the negotiations by compelling the stewards to acknowledge their shared interest in FMCG's competitiveness.

Take this message out to your members: 'it's not about money, it's about changing this business . . . it's about protecting - perhaps - the jobs of your members'. If [negotiations] stay on the level of reward then all of us in this room have failed to communicate the need for change . . Every change in working practices is not an opportunity to put your hand out. We have to change the way our employees look at the Golden Goose called FMCG.

We need to raise the game - this isn't about pay rises, it's about heading off disaster in two to three years' time.

Such a stance had huge implications not only for shopfloor workers, but also for managers, and senior management were happy to tell stewards that they would play 'hardball' on their own side. In response to steward concerns over line management's inability to change, the HR director responded: 'we'll encourage them, train them and then, if they've still not changed, we'll sack them'. By endorsing integrative bargaining, stewards were assured that management opportunism would not be tolerated. Effectively, integrative bargaining would compel operational managers to accept restrictions on their power and some redistribution of their authority in favour of the partnership and the stewards. Reshaping work organisation and the employment relationship was, then, a necessary precondition for job security. This was the rhetorical couplet that the shop stewards were to use to sell the agreement on the shopfloor. This was not a rehearsed intervention and stunned the management team. In private, the HR director shrugged: 'I don't know where that came from'. Walton and McKersie (1991: 354), similarly, 'were continuously amazed' at the tactical astuteness of experienced negotiators: 'the action-reaction behaviours came so rapidly and instinctively that the participants simply could not be selecting their behaviours consciously. Like a skilled boxer or basketball player, a skilled negotiator produces many types of appropriate behaviours on the basis of minimal cues from the situation and with virtually no mental planning'.

By the end of the first week, the negotiations process was spilling out of the formal setting. Increasingly, private meetings between key managers, union officials and convenors triggered each fresh initiative. The parameters of the formal agreement were established informally. It was here that the key players were willing to show their hands (see Kolb, 2004). A rapport quickly developed between the HR director and the two union officials, based on their self-perceptions as guardians of 'the big picture', a frank approach to discussions, and an appreciation of their respective negotiating stances. This was paralleled by the deepening of the increasingly 'cosy relationship' between the GMB convenor and the employee relations manager, both acutely aware that they would be the 'deliverers' to the shopfloor.

Pragmatism and principle underlay management's strategy for the implementation of 'Watershed'. Blurring demarcation lines and changes in crew rostering were to be the responsibility of joint management-union project teams. For management, this shopfloor governance structure was the vehicle for legitimising the change process. Project teams carried costs and risks for FMCG. The new governance process could 
extend uncertainty over task and grading and generate local disputes. For the union officials, the proposed governance structure risked inexperienced stewards being marginalised inside the project teams: 'derecognition by inches'. Conversely, compressing all bargaining into the 'Watershed' negotiations maximised the officials' control. Both management and union officials had powerful reasons to retreat from the uncertainty of project teams. Bringing the project team agendas, particularly on pay and grading, into the negotiations process offered a 'quick hit' for management but it presented huge practical and policy difficulties. Ironically, their attempts to do so were perceived by the stewards as a sign of management's acceptance of their demands for clarity; most stewards massively overestimated management's strategic capability and viewed the delay in receiving information on grading as a deliberate attempt to unsettle them.

There was limited steward support for project teams, an initiative that would increase the pressure on them from their workmates and further stretch their limited authority. However, the alternative - compressing innumerable grading and training issues into the 'Watershed' negotiations - would make 'selling' the deal to the shopfloor much more complex. FMCG's 72 pay grades, further complicated by local allowances, had to be rationalised during the negotiations. 'Local agreements were the bane of our lives', explained one engineering shop steward, since only management had an overview of the company. Ironically, management was far from certain about the contours of the firm's internal labour market. As the engineers' official remarked: 'it has got to such a situation that management don't know what agreements there are'. The dynamic of local opportunism by both management and stewards limited the latter's endorsement of corporate moves to overhaul archaic working practices:

Nothing was used to your advantage. You felt as though everything was used against you, so it made you really hesitant to give the company a chance. Everything was confrontation . . . because you felt as though anything that you did for them was a show of weakness and they would take advantage of it.

For incoming production managers - 'caught in a jungle of local fiddles' - allowances were an affront to their authority but accepted as 'a necessary evil' to maintain workflow:

You need a lawyer at your side before you make even trivial decisions. All you're wanting to do is get the job done, get it done better-a bit better-(smiles) not fanny about with daft allowances.

Baroque complexity made the criteria for earnings and promotions opaque and collective bargaining at company level virtually impossible. For the GMB official, the payment structure privileged the stewards' tactical autonomy over a convenor-led strategy. Only by forcing FMCG to buy out all outstanding allowances and winning universal increases in process workers' rates could the GMB negotiators hope to secure broad support for 'Watershed'. This was the moment of greatest tension between the officials and stewards. For the stewards, the full-time official was not continuously accountable to the shopfloor and insulated from the uncertainties of 'Watershed'. The official's objective was to strike a quick bargain, while the stewards' reluctance derived from their anxiety that this was an agreement they would have to defend on the shopfloor, perhaps for many years. For the GMB stewards, the negotiating skills used by the official against management were paralleled inside the union negotiating team:

I like his attitude to management. He can be very offhand with management sometimes. I think he can put management down quite easily. But then he also tries that with the stewards as well. I think he has to realise that there is a difference, because we are the people that represent the shopfloor. 
The FTO was willing to ridicule stewards in ways which were difficult for them to refute, steeped as it was in aspirations towards more 'dignified' labour. In response to stewards' opposition to self-managed breaks, he rebuked them:

Don't tell me it's beyond us to manage going to the toilet, or on a smoke break-don't tell me we need a manager, a bell or an alsatian dog to tell us to do it.

The complex relationship between the union official and the stewards and management was vital to the negotiations process. With the stewards the official had to play a double game. By privately reassuring management he was pressing for acceptance'I'm getting a fucking ulcer in there-fighting your battles, using your arguments' - he increased the authority of his argument about the price of shopfloor acceptance. Inside the stewards' meetings, the GMB official insisted that management could alter contracts unilaterally: 'we know we're going to take the fucking medicine-it's how we take it'. Again, only by accepting integrative bargaining could the stewards hope to reinstate distributive bargaining. Equally, he could not disable the stewards by limiting their role to merely ratifying his deal with management.

The stewards have come on a ton. It was like a training session for them. A lot of them were inexperienced. At first it was, 'No, No, No'. So I had to get them away from that: you've got to engage in debate with management-you can't just leave the field to them. This stuff-Watershed-is too important to be left to bosses [GMB official].

The stewards 'dug in' when their constituents' earnings were threatened. For the stewards, pressurising their official and, through him, management, significantly increased the value of specific buyouts. This success both ensured that the stewards regarded 'Watershed' as their deal rather than the official's and gave them a powerful example of where the negotiations had delivered significant local improvements. 'The price tag is all that fucking matters to the stewards, they don't really expect management to really come after all the dodgy practices' (GMB official, informal meeting with HR director). In private negotiations with management, the GMB official explained that compensation for lost allowances was vital to securing shopfloor endorsement. The continued vitality of distributive bargaining was signalled by monetary concessions and was vital in building the legitimacy of integrative bargaining. The FMCG workforce were 'allowance junkies':

So what do we do-let them go cold turkey? We must reach out to the people who want to be here in three years, 15 years. How do we deliver on this without the money to pull the members through the process? Money is very important.

Management conceded ground on buyouts as a one-off cost, secondary to long-term efficiency gains. The final element of the deal was to simplify the grading structure from 72 to four pay bands. Management's initial position was that the new wage structure would involve 'no losers', but this shifted to an 'all winners' tactic as management sought to increase the chances of workforce ratification. While management were privately aware that minor additions to wage rates were a small price to pay, in corridor meetings they maintained they had conceded much more than anticipated so increasing the need to deliver real changes in working practices: 'Listen you bastards, what you have here isn't a fucking offer, it's a fucking pools win'.

Both the officials and many stewards were in no doubt about the absurdity of some working practices, and that employees' manipulation of existing practice had signalled to management the possibilities for rationalisation: as the GMB convenor noted, 'every job lost at K-plant was due to doubling up ... what are we defending 
here? Against more intense working or the right to extra breaks?' Again, the FTO mocked the stewards' short-sightedness: 'Do we never go back on any concessions? OK, you can keep tea breaks, but there'll be no employment security, no staff status and no training'.

Negotiations with AMICUS paralleled the process workers with all parties coming together for the opening sessions and intermittently afterwards. The engineers were more cohesive than the process workers with far fewer contractual variations. The engineers resisted FMCG's overtures about employee involvement and teamworking that threatened to undermine 'the snobs of the shopfloor'.

This is the big fear. [Management] will have us working on the machines and having us work as a machine operator when we are quiet and letting women out to the toilet. I haven't served four years of my time and worked 20 years [as an engineer] to put labels in a machine.

Strategic strength and craft combativeness made the engineers a formidable force. The average engineer in FMCG was able to earn between 50 and 100 per cent of their base rate through overtime and ad hoc allowances. Production management were acutely aware that they had little control over the engineers: 'Bastards. They don't work for FMCG, they work for each other' (operations manager at HR director's Q\&A). But management could not hope to win a protracted war of attrition. 'The engineers, they're the fucking key, and they fucking know it'. As the HR director reminded senior operations managers,

They've got the fucking keys of the kingdom jangling in their pockets. Now, we can't force them to give them back, we can't steal them, so all we can hope to do is buy them back. There's no good getting precious or angry about this - these cunts have got us over a barrel. These guys are so important that we want them to be crawling over us to get to the deal.

A basic salary some 15 per cent over the industry norm, subject to upskilling, extensive buyouts of existing allowances and working practices, plus an enhanced standard overtime rate were the central elements of the offer to the engineers. Pragmatism dictated that the engineers could not be allowed to see themselves as wresting concessions from the company but rather that FMCG initiated these major contractual and work organisation changes. For the HR director, metaphorically, 'we've got to take them out for a drink, buy them a curry, take them home, let them shag the wife. [Pause] Then wake them up with a smile and breakfast in bed'. For production management, 'Watershed' had not secured victory over the engineers but reshaped the terrain. 'Watershed' legitimised a management focus on reducing change-over times, preventative maintenance and controlling the engineers through new institutions, notably ‘quick-action' project teams.

During the final phase of negotiations, there was increasingly formal and informal contact between individual managers and stewards discussing the implementation of 'their' deal. The final symbolic gesture in the negotiations involved the HR director leading the management team in a pre-arranged 'hug-a-steward' session. For FMCG, the negotiations process was a major breakthrough: a major reduction in fixed costs achieved through voluntary redundancy, a negotiations process completed in just three weeks, a rationalised internal labour market, and the elimination of gross inefficiencies and the gradual embedding of teamworking. The unions felt they had made gains: from being a negotiation which, management emphasised, was not about pay, pay has risen for all groups except shift workers; workers also gained a three-year job security pledge, rather than two, an enhanced buy-out arrangement and a commitment to training. There were sufficient departures from the original document to 
enable stewards to feel that they had forced management's hand, a view which management negotiators endorsed. All parties in the formal negotiations emphasised its distributive elements and discounted integrative gains and losses. Demonstrably effective distributive bargaining was essential to the legitimacy of the integrative elements of 'Watershed'.

\section{SELLING 'WATERSHED'}

The first three days back in the plants were dominated by large-scale presentations by management and union officials. The stewards and departmental managers were silent members of the platform party. The objective was to shape informal workplace debate and to boost the stewards' standing: 'it's about taking the heat off the stewards. If we didn't do this', the GMB official explained, 'there'd be bush fires all over the place'. The meetings largely passed off in sullen silence punctuated by angry shouts or sarcastic asides. 'We're not trying to sell this for you today', the GMB official consoled a disconsolate management team, 'it's not going to be a satisfying experience'. The vehicle for selling the deal was a series of joint presentations, followed by a union meeting, to groups of between 30 and 40 employees. The AMICUS stewards stood aloof from this 'visible jointness' for tactical reasons since a management presence would be resented as an intrusion into the union's internal democracy.

The smaller meetings began with a familiar management presentation on FMCG's weak competitive position. The GMB official then insisted that the union's strategy was to maximise its influence inside the change process while protecting terms and conditions. The stewards remained mute, even when the managers left the room. By the end of the second day of the large-scale presentations, the 'jointness' script was word perfect. In the smaller departmental fora, this process went still further with managers and union officials affirming each other's position and, occasionally, borrowing phrases from the other's script.

There were only two sustained shopfloor attacks on the shop stewards. The first, over the buyout of overtime payments, was specific to around 40 shift workers, and was deflected by the GMB official's defence of the stewards' distributive success in securing compensation rather than an unrewarded, managerially imposed contractual change. The second challenge was more profound and widespread: that the stewards had exceeded their mandate by returning with a settlement rather than an offer, a deal that the shopfloor could not reject or modify, only ratify. But, mindful of the tactical necessity of buttressing shopfloor opinion behind 'Watershed', the GMB official insisted that rejection was not an alternative:

\footnotetext{
Rejection would send a dramatic message: we're not interested in job security; we're not interested in change. Rejection would mean a return to trench warfare. You know the tactics. They'd pick on someone and ask them to do something as a favour. Next day, 'Why aren't you doing that? She's doing it'.

No deal means no protection. There's a lot of protection in this document and we've got to grab that. Our votes give our consent. That's an important principle. When we ballot we give permission to go forward. If we reject, changes will be brought in under or over the union. The ballot is not just about 'Watershed'-it's about whether our union has a future in this place.
}

Seventy per cent of process workers and a substantial majority of engineers voted for 'Watershed'. This endorsement did not necessarily signify a commitment to teamworking or changed working practices. Rather, the ballot was the workforce's acceptance that the unions' strategic arguments were sufficiently compelling to secure a massive vote for 'Watershed'. 
Much of the original workload planned for project teams was incorporated into the agenda for partnership committees. 'Watershed' has massively increased the stewards' workload so that on average between 30 and 60 per cent of their time was spent on official union activities. The transition to the new workplace increased the visibility of the unions in negotiating the details of work organisation, offering the possibility of a renewal of the strategic capability of shop stewards and greater membership participation (Fosh, 1993). This prospect also risked the stewards' fragile authority. Shop stewards had to participate in what were previously exclusively management processes to sustain or extend union influence and yet ensure their independence within those processes (for contrast, see Darlington, 1994). Part of the stewards' authority was now bound up with maintaining the momentum and integrity of the 'Watershed' project. Stewards became both representatives accountable to their shopfloor constituencies and delegates from 'Watershed'. Engineering stewards were acutely aware that their negotiating role inside the change process altered their role as shopfloor delegates and laid them open to charges of incorporation:

If I am constantly coming back to them and saying, 'we have got to do this, we have got to do that, we have got to do the other', then I am a tool of management. And I see that myself. There are certain things I will not get involved in.

Particularly for AMICUS stewards accustomed to acting solely as 'a defensive unit', this was a fine line. While management constantly attempted to widen the scope of 'Watershed', the stewards had to evaluate which initiatives to endorse 'because if I take them all forward then I am just being a management message boy'.

The company has stated on numerous occasions before, during, and since 'Watershed' that they were not out to marginalise the unions. But as a steward you could view it that they have done so by opening up the communications where everybody has a forum to speak as individuals. The whole point of the union is that is you speak with the same voice but we have given up that collective right, that collective voice, by having so many forums where people are openly saying things. There is nothing wrong with these people speaking up, but it is what management are taking from all these different views. Can they then use it against the union to marginalise [the stewards]?

\section{CONCLUSION}

We began by outlining management's decision to base their negotiating strategy on union demands as the cost of introducing radical change. The unions were not external to management strategy but were, rather, an integral part of it. Management's greatest strategic powers were those of last resort - 'we have no back-up plan: it's Watershed or Apocalypse Now' - compulsory redundancy and the imposition of rewritten labour contracts. Confrontation would neither secure the support of PLC nor lay the foundations for a transition to teamworking. Much of the substance of management's strategy was emergent rather than planned (Procter et al., 1994). The introduction of a simplified internal labour market, for example, was incorporated into the agreement at the insistence of the GMB and prompted a spurt of management improvisation. On reflection, the management team regarded emergence and improvisation as the essence of FMCG strategy. For the HR director, the agreement achieved both its tactical and strategic objectives. Tactically, FMCG management delivered the one-off reduction in fixed costs promised to PLC. Strategically, 'Watershed' opened up the prospect of a fundamental reshaping of shopfloor management and labour practices. 
'Watershed' established new shopfloor governance institutions and processes that altered the nature of the shop stewards' role. The uncertainties of organisational innovation imposed additional pressures on the stewards' representational function. In FMCG this has had the paradoxical effect of increasing the shop stewards' strategic capability coupled with a continued reliance on local, improvisational bargaining. Formal collective bargaining significantly altered the terms of engagement inside FMCG. Formal agreements such as 'Watershed' cannot, of themselves, ensure radical shifts in informal relations or the labour process. The 'Watershed' negotiators established a new set of bargaining rules that imposed new and significant restrictions of the behaviours on their own organisations as well as each other. This cannot be explained solely by reference to interest-based bargaining: labour process change for managers and pay increases and job security for the unions. While 'Watershed' delivered short-term cost savings, management negotiators traded some of the power and authority of operational managers for union endorsement in return for more important long-term efficiency gains. Union negotiators, on the other hand, accepted the certainty of member criticism in return for short-term contractual gains and, more importantly, embedding union representation in the governance structures of the new workplace. This complex set of exchanges was predicated upon the mutual learning and the trust developed by management and union negotiators during the intense three-week negotiations and their joint assumption of securing workforce ratification of 'Watershed'.

In common with several commentators on union responses to new management techniques, we maintain that 'Watershed' did not achieve a wholesale subordination of labour to managerial objectives (Danford et al., 2005; Fairbrother and Waddington, 1990; Kelly, 1996; Martinez Lucio and Weston, 1992a; Oxenbridge and Brown, 2004; Stewart and Garrahan, 1995). Rather, both process and skilled shop stewards grappled with a much more fluid form of shopfloor industrial relations characterised as much by membership dissent and disillusionment as by consent and compliance. For this is the abiding paradox of partnership and the mutual gains workplace, unions 'had to adopt conflict strategies in bargaining to achieve mutual gains' (Bacon and Storey, 2007: 831).

\section{References}

Bacon, N. and J. Storey (2007), 'Conflict for Mutual Gains?', Journal of Management Studies, 44, 5, 814-834.

Batstone, E., I. Boraston and S. Frenkel (1977), Shop Stewards in Action (Oxford, Blackwell).

Black, J. and D. McCabe (1996), 'Mobilizing Consent: Paternalism and Cellular Manufacturing', International Journal of Human Resource Management, 7, 2, 534-552.

Brown, W. (1972), 'A Consideration of "Custom and Practice"', British Journal of Industrial Relations, 10, 1, 42-61.

Burawoy, M. (2003), 'Revisits: An Outline of a Theory of Reflexive Ethnography', American Sociological Review, 68, 5, 645-679.

Burawoy, M., A. Burton, A. A. Ferguson, K. J. Fox, J. Gamson, N. Gartrell, L. Hurst, C. Kurzman, L. Salzinger and S. Ui (1991), Ethnography Unbound: Power and Resistance in the Modern Metropolis (Berkeley, CA, University of California Press).

Danford, A., M. Richardson, P. Stewart, S. Tailby and M. Upchurch (2005), Partnership and the High Performance Workplace: Work and Employment Relations in the Aerospace Industry (Basingstoke: Palgrave).

Darlington, R. (1994), The Dynamics of Workplace Unionism (London, Mansell). 
Dunn, S. and M. Wright (1994), 'Maintaining the "Status Quo"? An Analysis of the Contents of British Collective Agreements, 1979-1990', British Journal of Industrial Relations, 32, 1, 23-46.

Fairbrother, P. and J. Waddington (1990), 'The Politics of Trade Unionism: Evidence, Policy and Theory', Capital and Class, 41, Summer, 15-56.

Foreman-Peck, J., S. Bowden and A. McKinlay (1995), The British Motor Industry (Manchester, Manchester University Press).

Fosh, P. (1993), 'Membership Participation in Workplace Trade Unionism: The Possibility of Union Renewal', British Journal of Industrial Relations, 31, 4, 577-592.

Friedman, R. and D. McDaniel (1998), 'In the Eye of the Beholder: Ethnography in the Study of Work', in K. Whitfield and G. Strauss (eds), Researching the World of Work (Ithaca, NY, Cornell University Press) pp. 113-126.

Geary, J. and W. Roche (2003), 'Workplace Partnership and the Displaced Activist Thesis', Industrial Relations Journal, 34, 1, 32-51.

Guest, D., W. Brown, R. Peccei and K. Huxley (2008), 'Does Partnership and Work Increase Trust? An Analysis based on the 2004 Workplace Employment Relations Survey’, Industrial Relations Journal, 39, 2, 124-152.

Heery, E. (1996), 'The New Unionism', in I. Beardwell (ed.), Contemporary Industrial Relations: A Critical Analysis (Oxford, Oxford University Press) pp. 175-202.

Ingram, P. N. (1991), 'Changes in Working Practices in British Manufacturing Industry in the 1980s: A Study of Employee Concessions Made During Wage Negotiations', British Journal of Industrial Relations, 29, 1, 1-13.

Kelly, J. (1996), 'Union Militancy and Social Partnerships', in P. Ackers, C. Smith and P. Smith (eds), The New Workplace and Trade Unionism: Critical Perspectives on Work and Organization (London, Routledge) pp. 77-109.

Kelly, J. (1998), Rethinking Industrial Relations: Mobilisation, Collectivism and Long Waves (London, Routledge).

Kelly, J. and E. Heery (1994), Working for the Union: British Trade Union Officers (Cambridge, Cambridge University Press).

Kolb, D. (2004), 'The Shadow Negotiations and the Interest-based Approach at KaiserPermanente', Negotiations Journal, 20, 1, 37-46.

Lewicki, R. and B. Bunker (1996), Trust in Organizations: Frontiers of Theory and Research (London, Sage).

Marginson, P., P. K. Edwards, P. Armstrong and J. Purcell (1994), 'Strategy, Structure and Control in the Changing Corporation: A Survey-based Investigation', Human Resource Management Journal, 5, 2, 3-27.

Marks, A., P. Findlay, J. Hine, A. McKinlay and P. Thompson (1997), 'Handmaids' Tale or Midwives of Change? HR Managers and Organizational Innovation', Journal of Strategic Change, 6, 8, 469-480.

Marks, A., P. Findlay, J. Hine, A. McKinlay and P. Thompson (1998), 'The Politics of Partnership? Innovation in Employment Relations in the Scottish Spirits Industry', British Journal of Industrial Relations, 36, 2, 209-226.

Martin, R. (1992), Bargaining Power (Oxford, Oxford University Press).

Martinez Lucio, M. and S. Weston (1992a), 'Human Resource Management and Trade Union Responses: Bringing the Politics of the Workplace Back into the Debate', in P. Blyton and P. Turnbull (eds), Reassessing Human Resource Management (London, Sage) pp. 215-232.

Martinez Lucio, M. and S. Weston (1992b), 'The Politics and Control of Trade Union Responses to New Management Practices', Human Resource Management Journal, 2, 4, $72-91$.

Milward, N., M. Stevens, D. Smart and W. R. Hawes (1992), Workplace Industrial Relations in Transition (Aldershot, Dartmouth).

Nicolson, W., G. Ursell and P. Blyton (1981), The Dynamics of White Collar Unionism: A Study of Local Union Participation (London, Academic Press). 
Oxenbridge, S. and W. Brown (2004), 'Achieving a New Equilibrium? The Stability of Cooperative Employer-Union Relationships', Industrial Relations Journal, 35, 5, 388-402.

Procter, S. J., M. Rowlinson, L. McArdle, J. Hassard and P. Forrester (1994), 'Flexibility, Politics and Strategy: In Defence of the Model of the Flexible Firm', Work, Employment and Society, 8, 2, 221-242.

Samuel, A. (2005), 'Partnership and the Cultivated Activist', Industrial Relations Journal, 36, 1, $59-76$.

Stewart, P. and P. Garrahan (1995), 'Employee Responses to New Management Techniques in the Auto Industry', Work, Employment and Society, 9, 3, 517-536.

Storey, J. (1992), Developments in the Management of Human Resources (Oxford, Blackwell).

Undy, R., P. Fosh, H. Morris, P. Smith and R. Martin (1996), Managing the Unions: The Impact of Legislation on Trade Unions' Behaviour (Oxford, Clarendon Press).

Walton, R. E. and R. B. McKersie (1965), A Behavioral Theory of Collective Bargaining: An Analysis of a Social Interaction System (New York, McGraw-Hill).

Walton, R. E. and R. B. McKersie (1991), A Behavioral Theory of Labor Negotiations: An Analysis of a Social Interaction System (Ithaca, NY, ILR Press).

Walton, R. E., J. E. Cutcher-Gershenfeld and R. B. McKersie (1994), Strategic Negotiations: A Theory of Change in Labor-Management Relations (Boston, MA, Harvard Business School Press).

Webb, J. (1996), 'Vocabularies of Motive and the "New" Management', Work, Employment and Society, 10, 2, 251-271. 